\title{
Navigating paradox: Towards a conceptual framework for activism at the intersection of religion and sexuality
}

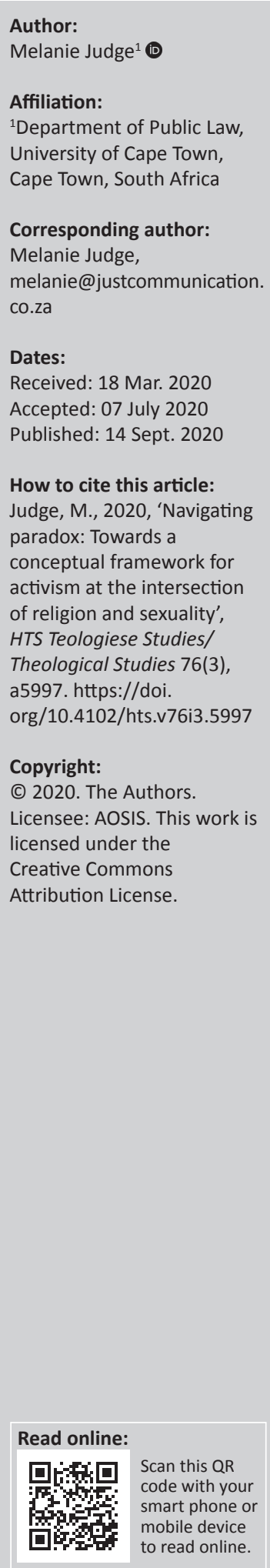

At the intersection of religion and sexuality, this article explores how lesbian, gay, bisexual, transgender, intersex and queer (LGBTIQ) people navigate dynamics of inclusion and exclusion within faith-based settings. Situated in a postcolonial setting, and with a specific focus on South Africa, the article delineates the oppressive dynamics at work at this intersection, along with how these are resisted through contemporary forms of activism. Grounded in a feminist analysis of relevant literature and of the field of activism in question, and supplemented by interviews with key informants, the research offers a conceptual framework to advance transformative inclusion for LGBTIQ people within, and against, the dominant institutions, discourses and practices of faith.

Contribution: This article contributes to the field of scholarship that concerns activism on sexual and gender rights in faith-based settings. It straddles theory and practice, offering an epistemological grounding for political action that advances the rights of LGBTIQ people. In bringing practitioner insights into academic discourse, the article adds to the burgeoning academic enquiry in this area, and offers a conceptual approach for supporting existing and new initiatives against marginalisation, exclusion and violence at the hands of faith.

Keywords: Queer; Sexuality; Religion; Rights; Gender.

\section{Introduction: Keeping the faith}

Faith is a powerful shaper of identity and meaning that influences social norms, values, ethics and behaviour (Judge 2019b). All too often, though, organised religion does violence to those who do not conform to dominant gender and sexual codes. Yet religion and faith practices, more generally, are also potential sites for the advancement of sexual and gender rights and justice (Judge 2019b). Many lesbian, gay, bisexual, transgender, intersex and queer (LGBTIQ) people seek to 'keep their faith', namely, to claim their right to religious belief and expression despite that their churches, mosques or synagogues might not recognise them or uphold their human rights. Others leave their communities of faith as a result of the prejudice, discrimination and exclusion they confront. Navigating these paradoxes is unavoidable when seeking to strengthen sexual and gender rights and counter marginalisation and violence done in the name of faith. At the same time that significant barriers inhibit equality, rights and justice for queer people; long-waged struggles have brought the question of sexual and gender discrimination out of the religious shadows (Judge 2019b). As Nadar and Van Klinken (2018:102) argue, whilst 'moral claims to religious truth fuel anti-queer sentiment', religious leadership, community and education can also 'play an important role in contributing to social change'.

Against this backdrop, this article develops a conceptual framework for the advancement of the rights of LGBTI people in faith contexts in South Africa. The framework is derived through a process of interpretation, synthesis and construction that is grounded in: a critical analysis of literature and praxes in the relevant activist field in South Africa; in-depth individual interviews with 10 key informants; and the author's own theorisation, critical reflections and insights as a long-standing queer and feminist scholar, practitioner and activist. ${ }^{1}$

1.The author is the co-lead of an activist project on the intersection of religion and sexual and gender rights in South Africa; she has been extensively involved in research, advocacy and law reform for LGBTIQ people over the past 20 years, and has served in leadership positions for numerous LGBTIQ organisations. Her work on sexuality and gender has been widely published. 
The key informants were purposively selected on the basis of their significant contributions to activism and scholarship on sexuality and religion in the South African context. $^{2}$

The article commences with an analysis of contextual factors - both contemporary and historic - that characterise the intersection of faith and sexuality in South Africa. It then sets out dominant resistances to sexual and gender diversity in organised faith milieus, with an emphasis on the ideologies and relations of power these represent. The article then presents a conceptual framework for supporting sexual and gender rights activism in faith settings.

\section{Sexuality and faith: Some contextual dynamics}

Institutionalised religion plays a central role in the organising and control of sex, sexuality and gender (see Haddad 2003; Tamale 2014). Orthodox theological interpretations, grounded in patriarchal worldviews, are held in common across mainstream organised religion. This is reflected in, amongst others, societal obligations to act and appear as a sexual and gendered person according to socially prescribed norms that are patriarchal, heteronormative and cisgendered. The Christian church, as an example, deploys heteronormativity and the concomitant denunciation of queerness as conditions for full and meaningful membership (Boesak 2019). As a regulatory system, gender shapes the conditions under which it is acceptable to have sex, to procreate and to form families and communities of belonging. These conditions in turn inform the roles, power and authority that one is allowed to hold within a religious community or structure, based on strict gender and sexual orders of inequality between men and women and heterosexuals and homosexuals. When gender and sexual hierarchies are challenged, the consequences are often stigmatisation and rejection which could culminate in physical or sexual violence. Against this backdrop, LGBTIQ people face multiple and intersecting discrimination at the hands of faith practitioners that relate to their sexual and gender status, as well as to race and class locations, amongst other factors. These intersecting discriminations have their historical bases in the imposed linkage of sex and sexuality with silence, shame and criminality during the colonisation of Africa. 'Colonial regimes [of which apartheid is one] routinely manipulated ideas about sexuality in order to maintain unjust power relations' (Collins 2004:87). The narrative of 'homosexuality as $\sin ^{\prime}$ was introduced to the African continent by Victorian missionaries who used the bible to advance colonial rule (Kaoma 2009). Control over African bodies (including sex and sexuality) was central to the logics of apartheid and colonial governance (Judge 2018a). This is most strongly evidenced in the penal codes introduced by colonising powers to regulate African sexualities, which included the criminalisation of same-sex sexualities, and intersection of religion and sexuality. See the acknowledgement section for more details on the informants. which were reliant on denials of rich traditions of African sexual and gender diversity (Judge 2018a). The historically imposed narrative of the singular, heterosexual African identity was central to this and was premised on the erasure of pre-colonial forms of sexual diversity (Epprecht 2008). These histories greatly impact contemporary attitudes towards sexuality across the African continent, raising the contention that, when it comes to transforming faith practices, '... we must take back our African contexts/realities' (West, Van der Walt \& Kaoma 2016:4).

Homophobia in postcolonial Africa is understood as a gendered strategy of political deployment ${ }^{3}$ to bolster nationalist leaders (Currier 2010). It also works as a defence of heterosexual African manhood against the 'threat' of homosexuality to deflect from the development-related failings of patriarchal rulers (Ratele 2014:116). Kaoma (2009) proposes that the denunciation of homosexuality by African leaders is more a politically expedient attack on the West than a definitive position on human sexuality. ${ }^{4}$ This is compounded by 'blackwashing', which is the racialisation of homophobia (Judge 2018a), and by its racial marking through the notion that homosexuality is 'un-African' (Gunkel 2010). Although the World Council of Churches and Christian councils of churches in the West largely hold progressive views on homosexuality, the majority of African church councils are opposed to it (Kaoma 2018:47). ${ }^{5}$ The upsurge of homophobia in various African countries in the last decade has been linked to the concerted efforts of US conservative evangelicals to: 'recruit a significant number of prominent African religious leaders to a campaign seeking to restrict the human rights of LGBT people' (Kaoma 2009:3). The attack of religious conservatives on the bodily autonomy, dignity and integrity of African women and African LGBTI people has been linked with what is described as 'US cultural wars' in which 'Africans have become a kind of "collateral damage" (Kaoma 2009:4). Attempting to undermine human rights gains back in the USA, these religious conservatives seek to legitimise their own ideological positions by misrepresenting 'mainline denominations' commitments to human rights as imperialistic manipulations of Africans into accepting homosexuality (Kaoma 2009:3). By extension, homosexuality is then framed as both a global and a local threat that calls for a transnational anti-LGBTIQ strategy (Defago, Faúndes \& Vaggione 2018). With this colonial history in mind, Boesak (2019) argues thus:

We rejected the apartheid pseudo-gospel because it claimed that the most important thing about a person is not that they are human beings created in the image of God the Liberator with inalienable rights, but their racial identity and pigmentation [...] All the arguments that were valid in the struggle against racism are applicable to the situation of LGBTQI persons. (p. 11)

3.Currier (2010:111) argues that political homophobia is implicated in historical erasures of gendered and sexual dissidence to buttresses 'phallic masculinity'.

4.Kaoma (2009) argues further that African reactionaries have exploited the false association of homosexuality with neo-colonialism to gain their legitimacy.

5.Ninety-eight per cent of African Evangelical leaders reject same-sex sexualities (Pew Research Center 2011:30). 
These dimensions of history also shape the language used to claim and express sexual and gender diversity over time, and this is primarily articulated through a western cultural and linguistic idiom. The lack of affirmative terms for queer expressions and experiences in vernacular languages reinforces the notion that they are 'going against the ancestors'. ${ }^{6}$ This is particularly significant given the limitations of the translatability of 'homosexuality' and 'homophobia' to identify and describe the prejudices that queers face (Sigamoney \& Epprecht 2013). The imposition of western terminologies in places where sexual and gender diversity has been violently denied exposes the constraints of the 'LGBTI' lexicon to represent sexual and gendered life in postcolonial contexts in affirming and non-stigmatising ways. Alongside this is the tendency to overlook the multiple and sometimes contradictory faith identities that African LGBTIQ people hold, including shared identifications with both Abrahamic faiths and indigenous African religious practices.

All institutionalised religions have a tendency to pit religious identity against queerness. ${ }^{7}$ This is constructed through representations of 'true' religious identity as inherently incongruent with LGBTIQ identifications; hence, it is antithetical to be both Muslim and gay, Jewish and lesbian, transgender and Christian, or queer and a sangoma (Judge 2019b). A consequence is that institutions, structures and practices of organised faith tend to enforce heteronormative gender and sexual expressions, frequently rendering them unwelcoming and unsafe for those with non-conforming sexual and gender identities. The fear of being ostracised, or of facing expulsion and other forms of discrimination, makes it difficult to be visible and to organise politically around sexual and gender rights within religious communities. These realities are enabled by religious discourses that denigrate and deny LGBTIQ people, casting them (out) as deviants, sinners and lesser humans. Such discourses have a significant influence on wider social norms, values and practices. Selective reading of sacred texts is used to justify the labelling of queerness as 'unnatural', 'ungodly' and 'sinful' (see Vincent \& Howell 2014). Hence, discrimination against LGBTIQ people is legitimised in and through faith, as material-discursive . $^{8}$ Reconciling one's faith identity with a non-conforming sexual or gender identity is a fraught terrain that has to be carefully navigated within religious contexts that still remain predominantly hostile to sexual and gender transgression.

The church in Southern Africa has been described as both an antagonist and an ally on matters of sexual and gender

6.Pharie Sefali, individual interview, 26 October 2018.

7.I deploy queer and queerness to dislodge the presumed coherences and binaries within and across 'LGBTI' identity formations and their categorisation. I am mindful too that sexual and gendered life is contingent, contradictory and always already in excess of categorical logics (including that of 'queer').

8. Here I refer to how the discourse of faith is material in that, as Hearn (2014) argues, discourse itself is inclusive of contexts, acts and effects. To approach faith as material-discursive accounts for how it constitutes realities and practices, and, consequently, how it is that discriminatory discourses of faith (e.g. 'homosexuality is a $\sin ^{\prime}$ ) have material impacts on people. diversity (Gunda 2017:27). Its dominant approach is to isolate particular biblical passages from their broader meaning and context, and to expediently present these as eternal truths based on interpretations that are ahistorical, prejudiced, moralistic and highly prescriptive (Pellot 2017:52-53). Significantly, though, sexuality has emerged as a much discussed issue in respect of theology and doctrinal practice across all mainline churches in Southern Africa. However, as one informant puts it, there is 'deep patchiness' in the extent to which issues of sexual and gender diversity are dealt with positively and productively in organised faith sectors. ${ }^{9}$ Some mainline churches (such as the Dutch Reformed, Reformed [Hervormde], Methodist and Anglican churches) have registered significant progress, whereas in others the question remains largely shrouded in silence (such as the Catholics, Evangelicals and African Independent Churches). Although some mainstream denominations in South Africa have adopted statements of inclusion, there are contradictions between these positions and church practices on the ground..$^{10}$ The Anglican Church's journey in dealing with same-sex sexualities in South Africa, for example, called the church to (Weeder 2018):

$[B]$ ecome alert to what feminist theologians refer to as 'texts of terror', [namely] those sections of the sacred text that, for example, depict sexual violence inflicted on women, without any critique. (p. 73)

Although there is a range of different sects within the practice of Islam in South Africa, a common-held position is that sexual non-conformity is potentially punishable with execution. ${ }^{11}$ There are also hadith that are mobilised to promote homophobia and which, by describing Islam as unchangeable, work actively against alternative, progressive Islamic paradigms. ${ }^{12}$ Navigating queer identity within Islam has been described as experiences of (Pellot 2017):

[B]latant rejection from orthodox Muslim communities, [which] has led many queer Muslims to negotiate this dilemma between sexuality and spirituality through assuming dual identities, drugs and alcohol abuse, irresponsible sexual behaviour, apostasy and even suicide. (p. 54)

In respect of traditional spiritual practices in South Africa, sangomas (traditional healers) are key figures in African communities who are called upon by the ancestors to provide physical, emotional and spiritual healing. Yet, 'LGBTQI sangomas are often considered strange and out of line with African ancestral beliefs', and as a 'disgrace that tests the ancestors'. ${ }^{13}$ As one informant expresses, 'the introduction of

9.Toni Kruger-Ayebazibwe, individual interview, 16 November 2018.

10.For example, the DRC's 'Season of Human Dignity' established grounding values for how the church was to approach human sexuality; however, this was directly undermined by the 2016 General Synod decision in respect of same-sex relations more recently overturned by a court of law (see Daily Maverick 2019). In a regional synod in the Diocese of Saldanha Bay, the Anglican Church decided in a landslide victory of 104-4 to allow for the blessing of same-sex marriages.

11.To legitimise this view, local Muslim leaders draw on pronouncements that are more than 1000 years old. Imam Muhsin Hendricks, individual interview, 26 October 2018.

12. Hadith refer to various interpretations of statements or actions by the Prophet Muhammad that shape contemporary practices of Islam.

13.Pharie Sefali, individual interview, 26 October 2018. 
Christianity made people see sangomas as barbaric'. Mainstream sangoma practices view gayness as a 'demon' and children are taken to sangomas to 'cure' them. Such practices are widespread, despite evidence that homosexuality has been a 'consistent and logical feature of African societies and belief systems' (Murray \& Roscoe 1998:iv). ${ }^{14}$ The religious rites of Christianity, Islam, Judaism and sangoma ceremonies share a reliance on gender-specific roles and obligations that assign masculinity and femininity as mutually exclusive.

Globally, in the name of 'religious freedom', religious conservatives have sought to counter feminist and LGBTI claims on full and equal citizenship (Defago et al. 2018):

The right to religious freedom is introduced as the other side of SRR (sexual and reproductive rights) and SOGI (sexual orientation and gender identity) rights, establishing an incompatibility between them and obliging states and human rights organisations to choose one or the other set of rights. (p. 12)

In this context, and on the basis of South Africa's constitutional principle of equality, discrimination at the hands of religious institutions has been challenged in courts of law. ${ }^{15}$ Key to these challenges has been democratic, public contestation over the role of religion and religious interpretation in defining sexual citizenship (see eds. Judge, Manion \& De Waal 2008). In balancing the right to religious freedom with the right to equality in respect of same-sex sexualities, the case law in South Africa is, however, 'still in development and without consensus' (INCLO 2015:21). Noting the limits of law in addressing LGBTI-related discrimination and inequality (Williams \& Judge 2018), radical change is also required, and, as Nadar and Van Klinken (2018:102) suggest, 'a critical interrogation of religion at the intersections of sexuality and gender in order to destabilise heteronormativity and patriarchy'.

\section{Resisting sexual and gender diversity}

Contemporary sexual and gendered identities, wrought from histories of violent subjection, have to contend with numerous oppositions in faith settings. In South Africa, there are a range of resistances that impact the extent to which sexual and gender diversity is approached progressively. This section thematically integrates key insights from the interviews with an analysis of the specificities of such resistances and the power interests they represent.

\section{Defending the dominant gender order}

One of the primary reasons why LGBTIQ people face such intense pushback in institutions of religion includes that they

14.For more on African histories of homosexuality, also see Admin76Crimes 2014.

15.This includes a number of high-profile court cases, such as Gaum and Others v Dutch Reformed Church (concerning the Dutch Reformed Church's position on same-sex relationships); De Lange v Presiding Bishop of the Methodist Church of Southern Africa and Another (concerning the firing of a lesbian minister fo marrying her partner); and Strydom v Nederduitse Gereformeerde Gemeente Moreleta Park (concerning the firing of a gay organ player). The cases show how increasingly, dominant religious practices are being scrutinised and challenged fo the extent to which they accord with constitutional principles of non-discrimination equality and dignity. are seen to pose a threat to male and masculine dominance by placing pressure on gender hierarchies to be reformed. Embodying a defiance of historical power structures (which remain predominantly male and heteronormative), the demand for recognition by those who are sexually and gender non-conforming forces a renegotiation of gender social relations. This is also related to the position and participation of women in religious communities and structures, and their implications for patriarchal religious traditions. Consequently, LGBTIQ rights are viewed as a threat to ruling gender and sexual orders. Fundamentalist interpretations of the sacred texts (be that the Bible, Torah, Quran or oral traditions) permeate everyday understandings of sexual and gendered embodiment. These rely on gender essentialisms, through, for example, the story of creation that entrenches and naturalises Western binaries of male/female, masculine/feminine and homosexuality/heterosexuality. Contesting these gender constructs is depicted as anti-religion. ${ }^{16}$ By extension, restrictive notions of 'family' and 'family-centred' ministries tend not to recognise divergent and non-conforming family formations. One informant indicates how religious ideas can 'destruct families instead of building them' as they deny how, in reality, families are constituted. By way of example, the arena of marriage is highly contested in religious institutions at a time when same-sex couples are increasingly asserting the right for their relationships to be equally recognised within these institutions. ${ }^{17}$

Many leaders of organised faiths are invested in the patriarchal and heteronormative discourses and ideologies through which they gain and maintain their power and privilege. This is given credence through interpretations of sacred texts that naturalise men's dominance in faith leadership, institutions and structures. The 'Abrahamic faith traditions are embedded in a patriarchal matrix' tied to gendered notions of 'the good life', 'the family', and to how to be a 'proper man or woman'. ${ }^{18}$ This is the normative social order that queers are perceived to threaten. ${ }^{19}$ Doctrines of theology are wielded against the acknowledgement of sexual and gender diversity: 'There are so many people who want to be kind, but the information they have is about the condemnation of homosexuality'. ${ }^{20}$ There is compounded by a lack of theological resources to engage with issues of diversity in an open and humanising manner. Moreover, inadequate theological education inhibits the capacity of trained clergy to deal with sex and sexuality, rendering them ill-equipped to engage with crucial arenas of human identity and interaction. The content and form of liturgical practice is frequently highly gendered and forecloses alternatives to 16.Zanele Makombe, individual interview, 16 November 2018.

17.More specifically, section 6 the Civil Union Act 17 of 2006 allows for civil marriage officers in the employ of the Department of Home Affairs to refuse to conclude same-sex unions on the basis of conscience (frequently attributed to religion). Some $37 \%$ of marriage officers object to concluding same-sex civil unions or marriages (Mudarikwa 2018). An amendment to the Civil Union Act is currently in proposal in the national legislature in the form of a private member Bill, the purpose of which is to repeal section 6 of the Act.

18.Toni Kruger-Ayebazibwe, individual interview, 16 November 2018.

19.Toni Kruger-Ayebazibwe, individual interview, 16 November 2018

20.Toni Kruger-Ayebazibwe, individual interview, 16 November 2018. 
heteropatriarchal modalities of doing faith. Yet, 'liturgy forms ideas and is a space in which innovation is a possibility' to approach God beyond a patriarchal, masculinist form..$^{21}$ As such, liturgy could become a sphere of participation rather than indoctrination and thereby 'an instrument to activate congregations to be sensitive to issues of inclusion' ${ }^{22}$

\section{A limited lexicon}

The lexicon for sexual and gender diversity is largely shaped by the Western idiom and is thus be expediently dismissed as 'foreign' to Africa. The lack of vernacular terms to speak of LGBTIQ experiences reinforces the judgement that people are 'going against the ancestors'. ${ }^{23}$ The limited vocabulary for sex is linked to the dualistic body-soul split at the core of JudeoChristian traditions, which disconnect religious beliefs from embodied identities. ${ }^{24}$ The foundational dualism that disconnects body from soul, and that shapes dominant theological worldviews, renders the realm of the sexual as one characterised by stigma and taboo. The (sexual) body is cast as impure and sinful, and control over it then becomes a mark of morality. ${ }^{25}$ Moreover, sacred texts work to naturalise gender and sexual identity (i.e. they construct the 'naturally heterosexual' man and woman). These naturalisations constitute the normative subject of religious belief - in relation to which the LGBTIQ believer is then rejected. Such constructs preclude people from engaging with the connection between religious texts and sexuality beyond the narrow frame of normalised heterosexuality and abjected homosexuality. ${ }^{26}$ Pervasive myths associated with sex and sexuality, and the absence of an informed and open language with which to talk of these issues, contribute to their systematic silencing. In this context, there is a dearth of understanding and knowhow of what it means to adopt a religious narrative and practice of gender and sexual inclusivity. This is exacerbated by heteropatriarchal interpretations of traditions that close the space for alternative articulations of faith in respect of sexuality and gender.

Culture and religion are, as one informant puts it, the 'terrible twins' of prejudice against LGBTIQ people. ${ }^{27}$ One effect of this is how, as Nadar (2005) posits, the 'unholy trinity' of culture, religion and gender construction promotes and sustains gender violence. The challenge queerness poses to both religion and culture is seen as 'going against everything we know as "true," and therefore as fiddling with the fundamentals' ${ }^{28}$ The co-deployment of heteropatriarchal culture and religious rhetoric to subordinate women and LGBTIQ people both produces and sustains hierarchies based on sex, sexuality and gender.

21.Teboho Klaas, individual interview, 17 November 2018.

22.Teboho Klaas, individual interview, 17 November 2018; and West 2019

23.Pharie Sefali, individual interview, 26 October 2018.

24.Prof. Charlene van der Walt, individual interview, 02 November 2018.

25.Prof. Charlene van der Walt, individual interview, 02 November 2018.

26.Teboho Klaas, individual interview, 17 November 2018.

27. Rev. Ecclesia de Lange, individual interview, 25 October 2018.

28.Toni Kruger-Ayebazibwe, individual interview, 16 November 2018.

\section{The vested interests of leaders}

The presence of homosexuality in the African context is characterised by the vitriol of religious leaders expressed through othering rhetoric (Bongmba 2016). At the level of institutional leadership, acceptance of LGBTIQ people where it does occur - takes an individualistic rather than systematic form. The tendency is to adopt a 'don't ask don't tell' approach which maintains a climate that abets the closeting of many LGBTIQ people..$^{29}$ The inability to call out the role of religion in perpetrating gender-based violence and hatred is a barrier to dealing openly and directly with discrimination when and where it occurs (see Ushe 2015; West, Van der Walt \& Kaoma 2016). Few systems and procedures have been created to facilitate the management of diversity within formal religious structures. This is coupled with a lack of interventions to equip faith leadership and lay people to deal with diversity and prejudice-related conflicts, particularly in contexts with burgeoning queer communities and expanding space for diverse gender and sexual expressions. One informant describes how religious leaders experience 'the fear of entering a terrain which is new for many ${ }^{\prime},{ }^{30}$ encumbering them in being proactive on matters of sexuality and gender. This is compounded by religious leaders' 'failure to interact with, and denial of, real lived experiences' ${ }^{31}$ Some leaders may harbour fears about openly engaging with sexual and gender issues, and this is linked to a perceived loss of their position and privilege. Others may exercise their power to thwart access for queer communities and to gatekeep their inclusion. Because leadership positions are linked to the dominant culture of the communities they serve, there is an anxiety about 'what would be left of the church' if such issues were tackled, demonstrating an inability or resistance to imagine the church anew. ${ }^{32}$ As many at the top of religious hierarchies are men, there is the idea that 'dominance should belong to a male and that we should protect him at all cost'. ${ }^{33}$ Read literally, selected sacred texts endorse this perspective. LGBTIQ faith leaders are frequently not called up to serve in religious institutions, and so they reach a glass ceiling within the leadership structures. ${ }^{34}$ Those who hold authority in these structures play a central role in defining the church and its praxes, yet what is meant by 'the church' and who constitutes it is seldom open for debate or challenge. ${ }^{35}$

\section{A religious politics of homophobia}

Gender and sexuality are politicised through religious homophobia (see Awondo 2016). This political deployment of homophobia by those in positions of authority is enabled

29.Rev. Laurie Gaum, individual interview, 24 October 2018

30.Teboho Klaas, individual interview, 17 November 2018.

31.Teboho Klaas, individual interview, 17 November 2018.

32.Teboho Klaas, individual interview, 17 November 2018.

33.Toni Kruger-Ayebazibwe, individual interview, 16 November 2018.

34.Rev. Laurie Gaum, individual interview, 24 October 2018.

35.Teboho Klaas, individual interview, 17 November 2018. 
through the use of religious discourse that is anti-LGBTIQ, anti-women and anti-democratic. Alongside this is a steady shift towards the privatisation of religion with its emphasis on individual experience, wealth and prosperity. The swing, particularly in Africa, towards Pentecostalism and its 'prosperity gospel', ${ }^{36}$ centres the promise of wealth accumulation as 'the answer' the church provides. In contexts of poverty and historical deprivation, this fictitious promise of faith as lucrative is attractive to many. ${ }^{37}$ Given the current anxieties about dwindling membership, of youth in particular, the charismatic model is seen as a success in drawing both numbers and resources to religious institutions. Growing in popularity and influence, the model is in direct contrast to religious traditions that approach devout communion as deeply concerned with, and rooted in, justice and diversity. ${ }^{38}$

\section{Towards a conceptual framework}

Despite the relatively small number of organisations dedicated to working at the intersection of faith and sexual and gender rights in South Africa, a vast array of strategies is pursued in this field of activism. Queer storytelling and oral history projects are methodologies that locate theological work within the lived experience of LGBTIQ people. ${ }^{39}$ Dialogue and engagement with faith leadership, grounded in contextual interpretations of sacred texts and using affirming terminologies to enable informed engage with sexual and gender diversity, are a leading approach. ${ }^{40}$ Also evident in the field are collaborative partnerships across academic and activist spheres and including national and regional convenings on sexual and gender diversity in the African context, and these facilitate cross-sectoral interventions. ${ }^{41}$ A focus on both academic and activist research is geared to producing bodies of knowledge on African genders and sexualities and their histories, whilst formal study curricula in higher education institutions harvest theologically trained graduates who are well versed in sexual and gender rights at the interface with organised religion. ${ }^{42}$ Advocacy, law reform (encompassing both civil and religious law) and lobbying through denominational decision-making structures remain key tactics. Strategic litigation that mobilises the constitutional

36.An apt description is prosperity gospel as 'the claim that simple faith in Jesus Christ will bring wealth and well-being' (Kaoma 2012:vii).

37.Zanele Makombe, individual interview, 16 November 2018.

38.Prof. Charlene van der Walt, individual interview, 02 November 2018.

39.See, for example: Gala, at www.gala.co.za.

40.See, for example: Inclusive and Affirming Ministries (www.iam.org.za), an organisation that works as a catalyst for transformation and greater acceptance and inclusion of LGBTI people within faith communities; and Al-Fitrah Foundation (www.al-fitrah.org.za), an organisation that raises consciousness through spirituality, access to information and movement building for Muslims who are marginalised based on sexual orientation and gender identity.

41.See, for example: Global Interfaith Network for People of all Sexes, Sexua Orientations and Gender Identities (GIN-SOGIEE), a membership-based network operating globally and with a specific regional focus on sub-Saharan Africa (www. gin-ssogie.org); and the Other Foundation (www.theotherfoundation.org) an African trust that advances equality and freedom in southern Africa with a particular focus on sexual orientation and gender identity.

42.See, for example: The School of Religion Philosophy and Classics and the Ujamaa Centre, University of KwaZulu-Natal; the Desmond Tutu Centre for Spirituality and Society, University of the Western Cape; the Gender Unit at the Beyers Naudé Centre, Stellenbosch University; and the Unit for Religion and Development Research, Stellenbosch University. framework to contest LGBTIQ-related discriminations within faith and customary institutions continues to be a primary approach to effecting institutional change. ${ }^{43}$ At the individual level, psychosocial support services are increasingly available to LGBTIQ people, parents and families within communities of faith. Leadership development in the sphere of queer religious activism to promote LGBTIQ-driven faith practices is also pursued. ${ }^{44}$ These strategies are supplemented by a range of training and public education initiatives focussing on human rights, faith and sexuality, gender equality and other related themes. There is also a growing body of material resources, tools and best practices on, for example, inclusive liturgy and ministering, working with clergy, and transformative pedagogies. ${ }^{45}$

Emerging from the previous discussion, what follows is a preliminary framework for how the advancement of LGBTIQ rights in faith settings can be conceptualised and approached. The framework comprises four overlapping and mutually reinforcing elements, namely, integrating faith and justice; intersecting African contexts and identities; challenging foundational discourses; and innovating for transformative inclusion.

\section{Integrating faith and justice}

The situation of the LGBTQI person is in its deepest reality a situation of injustice. Their search for the recognition and protection of their humanity is a search for justice. (Boesak 2019:12)

This element focusses on approaching the traditions, beliefs, institutions, roles and practices of faith as integrally linked to power. As a practice of material-discursive power, faith is implicated in systems of injustice predicated on inequalities related to sexuality, gender, race, class and other markers of difference. This requires particular attention to the intersection of sexism and homophobia and the gendered power relations it sustains (Msibi 2011). By viewing faith through the lens of justice, and gender and sexual justice in particular, the multiple and overlapping discriminations facing LGBTIQ people can be tackled together. The more advances made towards women's equal rights in a faith tradition, the more possibility there is for the recognition of sexual and gender diversity. In addition, integrating faith with struggles for justice also recognises how the racial oppression of colonialism and apartheid have shaped cultures of faith in South Africa, and how addressing these legacies and their contemporary continuities are central to shifting power arrangements in the sphere of religion.

The focus on justice provides a necessary counterweight to the pitting of rights against each other, such that the right

\section{See footnote 15}

44.See, for example: Ubom'bam Luvuyo Traditional Healers Forum in Cape Town, a support group and network of queer sangomas; and Queers Without Borders, a social media pressure group run under the auspices of the Moral Leadership Unit in the Faculty of Theology, Stellenbosch University.

45. For a more comprehensive breakdown of key strategies, actors and materials in the field, see Judge (2019a) 
to practise a religion in a particular manner is presented as conflicting or competing with the right to equality. The demand for equality therefore requires sustained interventions with faith leader allies who support social justice, to grow solidarity with, and support for, those still stigmatised and marginalised in and through faith. This invites mobilisations across ecumenical lines, against rightwing religious agendas, and around alternative, common national and regional goals. Through facilitated spaces for informed, values-driven dialogues, particularly with faith leadership, linkages can be strengthened between those working in the field and the larger social justice sector, thereby increasing the latter's recognition of faith as a critical site of struggle against injustice. Strategic collaborations and advocacy - both formal and informal are also to be deepened. At the local level, this includes strengthening pressure groups and queer movementbuilding to influence decision-making bodies (such as Synods, Councils, assemblies, Fatwa bodies or Ogogo). ${ }^{46}$ At the ecumenical or non-sectarian level, this concerns promoting the establishment of networks that bring significant players together to better coordinate efforts and to identify entry points for collaborative efforts. Important too are regional convenings on policy advocacy, the establishment of interfaith consortia and networks, and theological training and resource development to expand the pool of skilled and networked people, including clergy, who can take up issues at the community level. Civic and political education for LGBTIQ activists operating in faith communities will further locate queer rights within a broader terrain of social justice, cognisant of, and responsive to, the multiple and intersecting marginalisations and discriminations that LGBTIQ people face.

As one informant puts it, 'gender equality is the first biggest hurdle and sexuality is secondary to that ${ }^{\prime}{ }^{47}$ Here, feminist thinking and politics have a particular contribution to make in the struggles for justice of LGBTIQ people and in the light of the intersections of gender and sexual oppressions within organised religion. All organised religions have an interest in how life is governed and thus in the rules and regulations around which social and culture practices are organised. For this reason, LGBTIQ activism in the sphere of religion should concern itself with how conditions of life are shaped by law and policy, both inside and outside of religious structures. This includes policies on gender and sexuality, on sexual and reproductive health and rights, on traditional practices, on social development, and on gender-based violence and abuse, amongst others. Important here is lobbying for progressive shifts in religious and civil laws and policies through LGBTIQ organising. Setting in place standards and procedures for tacking injustice within faith settings is also critical, including the establishment of minimum standards to regulate

46.A Fatwa body is an institution consisting mainly of 'Muftis' (those who inform Islamic religious rulings). The elders ('Ogogo') are the decision-makers in the Islamic religious rulings). The elders ('Ogogo')
context of sangoma communities and practices.

47.Jacqui Benson, individual interview, 26 October 2018. institutionalised practices such as pastoral care. For example, in the light of homophobia, there is a call to 'meet a minimal pastoral threshold' (West, Van der Walt \& Kaoma \& 2016:6).

\section{Intersecting African contexts and identities}

[By] unmasking the colonial silence, African Christians can adequately address various issues associated with human sexuality while celebrating the sacredness of sexual diversity. (Kaoma 2016:69)

This element draws attention to the centrality of African sexual and gendered histories and experiences within contemporary faith contexts. It involves queering African faiths, and bringing traditional faith practices into closer conversation with Abrahamic traditions by promoting historical and contextual approaches to matters that concern African sexual cultures and identities. An area of under-exploration in this respect is the intersection of Abrahamic faiths and African traditional religions, and the decolonisation of faith practices, for example, the assertion of queer African sexualities as a decolonial act. Key to this is working with the interconnections of institutionalised faith traditions across African traditional, Islamic and Christian practices, which are sometimes co-existing forms of belief, identity and belonging. Moreover, through contextual readings of sacred texts in ways that consider their origins, authorship and implications for contemporary African societies, the relevance of these texts to diverse and dynamic African realities is enhanced. In this respect, African theology has the potential to break normative taboos through inclusive conceptions of African Christian identity (Van Klinken \& Gunda 2012). This is particularly important because, 'historically, the process of proselytisation subverted, overthrew and demonised African traditional religions (ATR), which formed an integral part of African sexual culture' (Tamale 2014:152). For example, African cultural traditions can also be read as viewing same-sex sexuality 'as a sign of a respected ancestral spirit rather than a demon possession' (Kaoma 2012:vii). In addition, values of $u b u n t u$ can be deployed to counter dogmatic religious opposition to LGBTIQ rights (Bongmba 2016; Epprecht 2013; Tamale 2014). As one informant says of African traditional belief systems, 'we all have to believe in something but that shouldn't come at the cost of losing some of who you are'. ${ }^{48}$ This requires queer interfaith work - recognising that some of the narratives that underpin justifications of prejudice (such as the biblical tale of Sodom and Gomorrah) exist across different belief systems.

\section{Challenging foundational discourses}

Like the waves, a moment before they dissolve back into the deep, biblical texts have been delivered to readers and believers as stable, coherent narratives at work in the service of the norm. Yet, the essence of the wave is the ocean; from the chaos comes (the appearance of) creation, then it folds (or crashes) once again into the chaos. We are not dealing here simply with queer 48.Pharie Sefali, individual interview, 26 October 2018. 
interpretation of the Bible; the Bible is always already queer. (Hornsby \& Stone 2011:xiii)

Significantly, religious discourse has been mobilised historically to vilify queer people; however, religious sense-making of homosexuality in Africa remains highly contradictory and contested (Awondo, Geschiere \& Reid 2012). Challenging the foundational frames of religious thought is needed to disrupt the normative narratives that keep intact hierarchies of inequality, based on sexuality, gender and race.

Significantly, LGBTIQ people should be at the centre of public discourses of faith that directly affect them, in particular those who deny and denounce queer African histories and experiences. This element's emphasis is on the development and centring of LGBTIQ-affirming discourses, together with movement building - within, across and outside of faith communities. Developing tools and capacities for inclusive language is necessary to create faith contexts that are facilitating of sexual and gender diversity. This requires a shift in the discourses of faith towards enabling norms and ideas related to rights, equality, justice and dignity to find more space. Engaging faith leadership through an examination of power remains vital. This involves working through the lens of power by: 'getting people into the room' on issues of sexuality; acknowledging how religious power operates (i.e. the benefits and interests associated with holding particular beliefs); and recognising how certain voices and positions are silenced through language and/as power. ${ }^{49}$ Such work seeks to disrupt how religious power can silence and marginalise particular experiences and exposes faith leaders to contextually based understandings of doctrine and its socio-historical implications..$^{50}$ Dialogue, as opposed to polarising debate, in which LGBTIQ experiences are at the centre, supports such work.

Queer religious activism can serve to amplify the voice and visibility of those who are marginalised and oppressed as the location from which alternative, transformative practices are emerging. Confronting dominant myths, including that there is one 'true' reading of holy texts and that queerness is anathema to African history, sexuality and culture, is a central strategy to shifting exclusionary faith practices. Enabling LGBTIQ people to integrate their sexuality and spirituality can be enhanced through psychosocial support and by facilitating the take up of queer religious activism. Strengthened educative spaces on human sexuality that draw on theoretical concepts (such as 'heteronormativity' and 'intersectionality') can expand a faith-appropriate lexicon that accounts for the multiple and interconnected injustices queers face. Closer links between LGBTIQ organisations and faith institutions will increase proximity to queer realities as a means to challenge 49.This is the methodology of Inclusive and Affirming Ministries (Reygan 2018). 50.IAM argues for readings that understand the cultural contexts in which the Bible's authors lived, how specific verses fit into larger passages within the Bible's overal message, and how verses can be read in a contemporary context (Pellot 2017). discriminatory exclusions exercised 'in the name of religion' by exposing its lived material effects. In challenging foundational frames, the emphasis is on reimagining decontextualised, heteropatriarchal discourses of faith in favour of historicised, affirming and inclusive ones.

\section{Innovating for transformative inclusion}

The ruling of the South African Constitutional Court [on the decriminalization of sodomy] removed the statute that criminalised same-sex intimacy ... In so doing, it presented the Church with both a gift and challenge. This decision gifts us with an impetus, a resource that focuses our attention, spiritually and pastorally. (Weeder 2018:72)

This pillar calls for the promotion of practices of inclusion in the interpretation of sacred texts, the doing of ritual, and in liturgy, structures, systems, leadership and practices. It stresses the need for exemplars, role models and tools to demonstrate what radical and transformative gender and sexual inclusion looks like in real terms. Identifying champion communities of faith that model affirming and inclusive practices can enhance and support the imaginative (re)use of faith language, concepts and rituals in liberating ways, for example, Eucharist as form of radical inclusion. ${ }^{51}$ Promoting inclusive liturgical practices through, for example, inclusive liturgy-writing workshops, guidelines on how to practise inclusion as a faith leader, and best practices of inclusion can further enhance such efforts. Showcasing the ways in which LGBTIQ people embody the possibility of more just and equitable modalities of faith, along with oral histories of their vulnerability and resilience within communities of faith, serve as exemplars for change. Targeted research on the intersection of faith and gender or sexual diversity is necessary to document transformative practices in relation to, amongst others, liturgical practices; inclusive leadership; intra- and inter-faith lobbying; and queer and allied resistance to discriminatory and exclusionary faith structures and practices.

The multiple strands of African theology reveal how too 'dissident voices break the taboo and develop more inclusive concepts of African identity and African Christianity' (Van Klinken \& Gunda 2012:114). An active 'acknowledgement of sex' can provide religious leaders with a positive resource to 'enrich the received religions by introducing more realistic, vibrant and passionate traditions from indigenous African cultures' (Amadiume 2006:7). This requires 'expand[ing] our sex knowledge about the ambiguities and positive messages from cultures, religions, literature and science' (Amadiume 2006:9). Orthodox beliefs on sex, sexuality and gender can be challenged by centring the lived experiences of LGBTIQ people, frequently overlooked in traditional models of faith leader training. Such transformative work on gender and sexuality demands the living presence of LGBTIQ people in that 'diversity requires real diverse bodies' ${ }^{52}$ Tools are needed to support clergy to 'wrestle with the doctrine' in ways that 51.Prof. Charlene van der Walt, individual interview, 02 November 2018. 52.Prof. Charlene van der Walt, individual interview, 02 November 2018. 
open liberatory alternatives to those who sow bigotry and hatred..$^{53}$ One informant expresses this as the act of 'saying no to the verse', that is, refusing certain texts if their interpretations have fundamentally unjust implications. ${ }^{54}$ In the context of Islamic practices, for example, this invites 'alternative interpretations of divine texts and develops their potential to reinforce the Quran's inclusive nature which promotes equality and freedom of choice' (Hendricks 2010:31). In this way, and drawing on liberation theology, the texts and oral histories of faith can be interpreted in ways that subvert, rather than perpetuate, contemporary injustices.

\section{Conclusion}

What ultimately matters, is whether manifestations of religious freedom cause harm to others. (INCLO 2015:49)

It is indisputable that the exclusion, stigmatisation and marginalisation of LGBTIQ people in the name of faith cause significant harm. In fact, it is argued that 'traditional normative theologies of sexuality have traumatised queer Christians' (West, Kaoma \& Van der Walt 2017:13). In this context, a case recently won in the High Court is instructive. The applicants, a group of queer ministers, argued that the struggle for queer recognition in the church is a struggle for the right to religious freedom itself. ${ }^{55}$ They assert that the denial of this recognition violates religious freedom in that church leaders (Judge 2018b):

[H]ave imposed their religious beliefs on others, manifesting their own beliefs in a manner which not only disqualifies the latter from exercising their self-same religious rights - but also simultaneously infringing other constitutionally-entrenched rights, inter alia the rights to equality and dignity. (n.p.)

This article has sought to analyse some of the dynamics that drive these rights violations in faith settings, offering a conceptual approach for supporting existing and new initiatives that counter ongoing marginalisation and violence. Yet, oppressive belief systems can only be undone by giving voice to those who are at the receiving end, be it on the basis of sex, sexuality, gender, race and/or other social positionings. The radical prospect is for queers - alongside others who are marginalised by religious orthodoxies - to envisage and enact more equitable forms of faith practice from the margins. Critically, this places the embodied presence of those at the margins in the centre of struggles for justice. Ultimately, a vision and praxis of radical and transformative gender and sexual inclusion is the imperative - with or without faith.

\section{Acknowledgements}

Acknowledgement and thanks go to the key informants: Rev. Laurie Gaum (Queers Without Borders), Rev. Ecclesia de Lange (Inclusive and Affirming Ministries), Pharie Sefali (Ubom'bam Luvuyo Traditional Healers Forum), Jacqui

53.Toni Kruger-Ayebazibwe, individual interview, 16 November 2018.

54.Imam Muhsin Hendricks, individual interview, 26 October 2018.

55.See Gaum and Others v Dutch Reformed Church.
Benson (Temple Israel Jewish Congregation), Prof. Charlene van der Walt (School of Religion, Philosophy and Classics, University of KwaZulu-Natal), Imam Muhsin Hendricks (Compassion Centred Islam), Prof. Sarojini Nadar (Desmond Tutu Centre for Religion and Social Justice, University of the Western Cape), Zanele Makombe (Act Ubumbano), Toni Kruger-Ayebazibwe (Global Interfaith Network for People of All Sexes, Sexual Orientations, Gender Identities and Expressions) and Teboho Klaas (Other Foundation). Appreciation also goes to Prof. Andries van Aarde.

\section{Competing interests}

The author declares that she has no financial or personal relationships that may have inappropriately influenced her in writing this research article.

\section{Author's contributions}

M.J. is the sole author of this research article.

\section{Ethical considerations}

This article followed all ethical standards for research without direct contact with human or animal subjects.

\section{Funding information}

This article is based on the research that was supported by the Heinrich Boell Foundation Southern Africa's Keeping the Faith project, and by the South African Research Chair's Initiative of the Department of Science and Technology and National Research Foundation of South Africa (Grant No. 47303).

\section{Data availability statement}

Data sharing is not applicable to this article as no new data were created or analysed in this study.

\section{Disclaimer}

The views and opinions expressed in this article are those of the author and do not necessarily reflect the official policy or position of any affiliated agency of the author.

\section{References}

Admin76Crimes, 2014, 21 varieties of traditional African homosexuality, viewed 03 July 2019, from https://76crimes.com/2014/01/30/21-varieties-of-traditionalafrican-homosexuality/.

Amadiume, I., 2006, 'Sexuality, African religio-cultural traditions and modernity: Expanding the lens', Codesria Bulletin 1(2), 1-9.

Awondo, P., 2016, 'Religious leadership and the re-politicisation of gender and sexuality in Cameroon', Journal of Theology for Southern Africa 155, 105-120.

Awondo, P., Geschiere, P. \& Reid, G., 2012, 'Homophobic Africa: Toward a more nuanced view', African Studies Review 55(3), 145-168. https://doi.org/10.1017/ S0002020600007241

Boesak, A., 2019, 'Taking a stand: A call to action by the church against injustice towards LGBTI people', The Other Foundation, viewed 02 November 2019, from http://theotherfoundation.org/wp-content/uploads/2019/09/Taking-a-stand.pdf.

Bongmba, E.J., 2016, 'Homosexuality, ubuntu, and otherness in the African Church', Journal of Religion and Violence 4(1), 15-37. https://doi.org/10.5840/jrv201642622

Collins, H.P., 2004, Black sexual politics: African Americans, gender and the new racism, Routledge, London. 
Currier, A., 2010, 'Political homophobia in postcolonial Namibia', Gender \& Society 24(1), 110-129. https://doi.org/10.1177/0891243209354275

Defago, M.A.P., Faúndes, J.M.M. \& Vaggione, J.M., 2018, 'Religious conservatism on the global stage: Threats and challenges for LGBTI rights', Global Philanthropy Project viewed 15 October 2019, from https://globalphilanthropyproject.org/2018/11/04/ religious-conservatism-on-the-global-stage-threats-and-challenges-for-lgbti-rights/.

Epprecht, M., 2008, Heterosexual Africa? The history of an idea from the age of exploration to the age of AIDS, Ohio University Press, Athens, GA.

Epprecht, M., 2013, Sexuality and social justice in Africa: Rethinking homophobia and forging resistance, Zed Books, New York, NY

Gunda, M.R., 2017, 'Silent no longer: Narratives of engagement between LGBT groups and the churches in southern Africa', The Other Foundation, viewed 15 October 2019, from http://theotherfoundation.org/wp-content/uploads/ 2017/01/Silent-No-Longer.pdf.

Gunkel, H., 2010, The cultural politics of female sexuality in South Africa, Routledge, London.

Haddad, B., 2003, 'Choosing to remain silent: Links between gender violence, HIV/ AIDS and the South African Church', in I.A. Phiri, B. Haddad \& M. Masenya (eds.), African women, HIV/AIDS and faith communities, pp. 149-167, Cluster Publications, Pietermaritzburg.

Hearn, J., 2014, 'Men, masculinities and the material(-)discursive', NORMA International Journal for Masculinity Studies 9(1), 5-17. https://doi.org/10.1080/ 18902138.2014.892281

Hendricks, M., 2010, 'Islamic texts: A source for acceptance of queer individuals into mainstream Muslim society', The Equal Rights Review 5, 31-51.

Hornsby, T.J. \& Stone, K.A., 2011, 'Already queer: A preface', in T.J. Hornsby \& K.A. Stone (eds.), Bible trouble: Queer reading at the boundaries of biblical scholarship, pp. ix-xiv, Society of Biblical Literature, Atlanta, GA.

International Network of Civil Liberties Organisations, 2015, 'Drawing the line: Tackling tensions between religious freedom and equality', International Network of Civil Liberties Organisations, viewed 05 November 2019, from https://www. cels.org.ar/common/documentos/DrawingtheLine.pdf.

Judge, M., 2018a, Blackwashing homophobia: Violence and the politics of gender, sexuality and race, Routledge, Abingdon.

Judge, M., 2018b, 'Queer rights battle is a fight for the right to religious belief', Mail and Guardian, viewed 08 October 2019, from https://mg co.za/article/2018-1009-00-queer-rights-battle-is-a-fight-for-the-right-to-religious-belief

Judge, M., 2019a, Keeping the faith: Working at the crossroads of religion and sexual and gender rights - A discussion paper on critical issues, actors, initiatives and opportunities, Heinrich Boell Foundation, Cape Town.

Judge, M., 2019b,'Tackling sexual and gender rights within the paradox of faith' News24, viewed 19 November 2019, from https://www.news24.com/news24/ columnists/guestcolumn/opinion-tackling-sexual-and-gender-rights-within-theparadox-of-faith-20190905

Judge, M., Manion, A. \& De Waal, S. (eds.), 2008, To have and to hold: The making of same-sex marriage in South Africa, Fanele, Cape Town.

Kaoma, K., 2009, Globalising the culture wars: US conservatives, African churches and homophobia, Political Research Associates, Boston, MA.

Kaoma, K., 2012, Colonising African values: How the US Christian Right is transforming sexual politics in Africa, Political Research Associates, Boston, MA.

Kaoma, K., 2016, 'Unmasking the colonial silence: Sexuality in Africa in the postcolonial context', Journal of Theology for Southern Africa 155, 49-69.

Kaoma, K., 2018, 'Contesting religion: African religious leaders in sexual politics', in Christianity, globalization, and protective homophobia, pp. 47-72, Palgrave Macmillan, Switzerland.

Msibi, T., 2011, 'The lies we have been told: On (homo) sexuality in Africa', Africa Today 58(1), 55-77. https://doi.org/10.2979/africatoday.58.1.55

Mudarikwa, M., 2018, 'The interaction between the right to equality and freedom of religion in South Africa: Exploring the Constitutionality of Section 6 of the Civil Union Act 17 of 2006', Legal Resources Centre, Equality \& Non-discrimination, viewed 22 September 2019, from http://Irc.org.za/art_external/pdf/2018\%20 LRC\%20Civil\%20Unions\%20Advocacy\%20Report.pdf.
Murray, S.O. \& Roscoe, W., 1998, Boy-wives and female husbands: Studies in African homosexualities, Palgrave, New York, NY.

Nadar, S., 2005, 'Searching the dungeons beneath our religious discourses: The case of violence against women and the "unholy trinity"', Agenda 19(66), 16-22.

Nadar, S. \& Van Klinken, A., 2018, “'Queering the Curriculum": Pedagogical explorations of gender and sexuality in religion and theological studies: Introduction', Journal of Feminist Studies in Religion 34(1), 101-109. https://doi. org/10.2979/jfemistudreli.34.1.16

News24, 2019, 'High Court scraps Dutch Reformed Church decision against same-sex marriages', Daily Maverick, viewed 03 July 2019, from https://www. dailymaverick. co.za/article/2019-03-08-high-court-scraps-dutch-reformed-church-decisionagainst-same-sex-marriages/.

Pellot, B., 2017, 'Covering sexual and gender minorities and religion in sub-Saharan Africa: A reporting guide for journalists', Religion News Foundation and Heinrich Boell Foundation, Cape Town, viewed 22 September 2019, from https://za.boell. org/sites/default/files/_print_final_4_web_1.pdf.

Pew Research Centre, 2011, 'Global Survey of evangelical protestant leaders', Pew Forum on Religion \& Public Life, viewed 15 November 2019, from https://www. pewresearch.org/wp-content/uploads/sites/7/2011/06/Global-Survey-of-Evan.Prot.-Leaders.pdf.

Ratele, K., 2014, 'Hegemonic African masculinities and men's heterosexual lives: Some uses for homophobia', African Studies Review 57(2), 115-130. https://doi. org/10.1017/asr.2014.50

Reygan, F., 2018, Creating dialogue on LGBTI rights within faith communities in Southern and Eastern Africa: Final evaluation IAM LGBTI project, HSRC Review, n.l.

Sigamoney, V. \& Epprecht, M., 2013, 'Meanings of homosexuality, same-sex sexuality, and Africanness in two South African townships: An evidence-based approach for rethinking same-sex prejudice', African Studies Review 56(2), 83-107. https://doi. org/10.1017/asr.2013.43

Tamale, S., 2014, 'Exploring the contours of African sexualities: Religion, law and power', African Human Rights Law Journal 14(1), 150-177.

Ushe, U.M., 2015, 'Eradicating sexual abuse and gender-based violence in Africa and America: Role of religious leaders', European Scientific Journal 11(5), 99-116.

Van Klinken, A.S. \& Gunda, M.R., 2012, 'Taking up the cudgels against gay rights? Trends and trajectories in African Christian theologies on homosexuality', Journal of Homosexuality 59(1), 114-138. https://doi.org/10.1080/00918369.2012.638549

Vincent, L. \& Howell, S., 2014, “Unnatural”, "un-African" and "ungodly": Homophobic discourse in democratic South Africa', Sexualities 17(4), 472-483. https://doi org/10.1177/1363460714524766

Weeder, M., 2018, 'Awakening to freedom: A global South perspective', Intimate conviction: Examining the church and anti-sodomy laws across the commonwealth pp. 71-74, Canadian HIV/AIDS Legal Network, viewed 28 July 2019, from http:// www.aidslaw.ca/site/intimate-conviction-volume/?lang=en.

West, G., 2019, 'Deploying indecent literary and socio-historical detail for change: Genesis 2:18-24 as a resource for choice of sexual partner', in L.J. Claassens, C. Van der Walt \& F.O. Olojede (eds.), Teaching for change: Essays on pedagogy, gender and theology in Africa, pp. 57-78, Sun Press, Stellenbosch.

West, G., Van der Walt, C. \& Kaoma, K.J., 2016, 'When faith does violence: Reimagining engagement between churches and LGBTI groups on homophobia in Africa', HTS Theological Studies 72(1), 1-8. https://doi.org/10.4102/hts.v72i1.3511

Williams, K. \& Judge, M., 2018, 'Happy (n)ever after? Public interest litigation for LGBTI equality', in J. Brickhill (ed.), Public interest law in South Africa, pp. 239-257, Juta, Cape Town.

\section{Case Law}

Gaum and Others v Dutch Reformed Church 2019 (2) SA 722 (GP)

De Lange $v$ Presiding Bishop of the Methodist Church of Southern Africa and Another 2016 (2) SA 1 (CC)

Strydom v Nederduitse Gereformeerde Gemeente, Moreleta Park 2009 (30) ILJ 868 (EqC) 